\title{
Health Promotion Management Model in Dealing with Tropical Diseases
}

\author{
Eddy Syahrial ${ }^{1}$, Destanul Aulia ${ }^{2}$, Logut Sutandra Siregar ${ }^{3}$ \\ ${ }^{I}$ Department of Health Education and Behavioral Sciences, University of Sumatera Utara, Indonesia \\ eddysyahrial@yahoo.com \\ ${ }^{2}$ Department of Health Policy and Administration, University of Sumatera Utara, Indonesia \\ destanul.auliaeusu.ac.id \\ ${ }^{3}$ Social Communications Department Political, Indonesia \\ eddysyahrialeyahoo.com
}

\begin{abstract}
Health promotion is a health program designed to make improvement such as a change in behavior in society, an organization or the environment, either physical, non-physical, socio-cultural, economical, political environment or others. PHBS (Clean and Healthy Lyfestyle Behavior) is the implementation of the realization of human rights that can be performed since early age, implemented in daily life, and be a model to other societies.

The objective of the research was to find out the behavior, attitude and act as well as the method and model of health promotion obtained from the society toward the PHBS of Padangsidempuan District.

This is a descriptive qualitative research. The samples were 25 household heads from each of four subdistricts in Padangsidempuan District which were 100 household heads in total to find out the level of knowledge, attitude and act toward PHBS and to find out the method and media that had ever been obtained.

The results showed that $73 \%$ of the respondents had moderate level of knowledge, $90 \%$ of the respondents had good Attitude, $53 \%$ of the respondents' response to tropical disease was dominantly poor. Apparently it was found that respondents' acts were not in accordance with their level of knowledge and attitude. The methods that had ever been obtained were preaching and discussion method represented by $32 \%$ and $17 \%$ respectively, and the rest of them had never received any kind of method of PHBS. It showed that they were at risk of the tropical diseases, proven from the high rate of pulmonary disease suffered from by the respondents because they had never obtained any information about the prevention of Pulmonary TB (Tuberculosis). The Media that had ever been received were Television represented by $33 \%$, yet it was merely about smoking, leaflet represented by $27 \%$ from the health personnel and university students, and religious sermon from Ustadz represented by $6 \%$. It was similar to the findings on method, $40 \%$ of the respondents had never received any information from any media, so that they did not have any information about PHBS.

It is recommended that the advocate of Health Agency and Public Figure implement the effective methods and media to promote PHBS to the society so that it will reduce the rate of tropical disease in Padangsidempuan District.
\end{abstract}

Keywords - Model of Health Promotion, Tropical Disease, PHBS Analysis, health agency, public figure

\section{Background}

A health promotion is aimed at revitalization health education in last time, in this case the health promotion concept is not only a process to assure public aware given and improve people knowledge just on health field, but also the effort how to be capable provide bridge how to change in one's behavior.

How to empowerment public existed should be started in home or family, for a health household is an asset particularly wishing for future development need to keep up, reinforced and to protect public health. Noted that some members in household has highly sensitive affected by either infectious and non-infectious diseases, therefore, in order to deal with the diseases, every member of household is highly encouraged to hold a Cleanly - Health Living Attitudes (PHBS).

Padangsidempuan city is one of districts in Sumatera Utara where some found people is least understanding about a health and cleanly attitude to live due to shortage education formally of health. According to a survey report on PHBS, under category of knowledge indicated that by 6 Kecamatan-sub district, in whole it can be classified moderately found in $63 \%$, is good noted only $37 \%$ and nothing found worst category. Still, category having knowledge PHBS moderately found such as Kecamatan Padangsidempuan Batunadua, Padangsidempuan Hutaimbaru, Padangsidempuan Selatan, Padangsidempuan Utara. In good knowledge on PHBS found Padangsidempuan Angkola Julu and Padangsidempuan Tenggara. 
Having attitude PHBS of people in good, found such as Padangsidempuan Angkola Julu and Padangsidempuan Tenggara. Community with PHBS attitudes of Kota Padangsidempuan is categorized in a moderately rate noted $70.7 \%$, good rate of $29.1 \%$ and on bad rate of $0.2 \%$. Still, in community, hold PHBS action on Kota Padangsidempuan is categorized as following, in moderately $97 \%$, good in $2.2 \%$ and bad category is $0.8 \%$.

\section{A. Formulating the Problems}

How it should attitude in Clean and Health Living (PHBS) and what is about to promote health program in actually and method of field counseling, how to use the media in field as categorized moderately correlating with a tropical diseases?

\section{LITERATURE REVIEW}

\section{A. Health Promotion Management}

A health management is a certain activities or at least method how to assign those medical or notmedical personnel aware in order to improve public health rate through health programs. "In particularly public health management is to apply a general management in a public health services system to become then an object and management target must be the public health services system itself' [8].

\section{B. Indicator in Successful of Health Promotion}

Indicator of successful is absolutely required formulated mainly to monitor and evaluate the health promotion [8]. The indicator of successful is comprising of input, indicator of process, and output.

\section{Indicator of input}

The input need to highlight such as commitment, human resources, facilities, and funds with target to individual, group, and community. So, these input indicator need to pay attention details before conducting health promotion.

\section{Indicator of Process}

The process to be monitored are process of providing health promotion to influence others, in this line such as media and methods to be used in health promotion.

\section{Indicator of output}

The output as expected in this health promotion such as a health behavior in conducive in order to improve and keep health seriously, comprising of:

1) Change of behavior, moved from inappropriate attitudes to a better health values.

2) Keeping in good, encourage community be healthy persistently.

3) Having advanced attitudes, encourage everybody to keep being healthy.

\section{Having Cleanly and Healthy Living (PHBS)}

Having cleanly and healthy in living (PHBS) is every attitude behaved with own aware that motivate him/her self keep healthy and play role actively in a healthy activities. Having a cleanly and healthy living in addition, is to implement basic human right, there can be done early time, make it habitual and daily action, and it should be model to other people[11].

A family hold PHBS attitudes perhaps in the home improved self the health and not visit any hospital. A healthy family can improve the work productivities. In order to rise the health rate of family up required investment cost such as for education and with other efforts possibly to improve family welfare.

There are ten indicators of having cleanly and healthy inliving :

1) Family with child-birth aided in medical personnel.

2) Baby with mother-feed exclusively.

3) Having baby and kid weight done routinely monthly.

4) Washing hand with clean water and soap.

5) Having clean water in home

6) Household with toilet existed.

7) Eradicated mosquito larva away from home

8) Having consumed vegetables and fruits sufficiently daily.

9) Having physical activities actively.

10)No smoking.

\section{THE AIMS OF STUDY}

\section{A. The Objective of Research}

The objective of this study are such as to know the details existed and to analyze the community with having cleanly and healthy living, about the process of health promotion management and to find the best 
model of health promotion conforming to the community health and its correlation to tropical diseases on Padangsidempuan city.

\section{B. The Purposes of Research}

The main purposes of conducting this research is to have valuable inputs to local administration, to Puskesmas and for community living on Padangsidempuan, and to encourage them to do daily healthy living after counseling by an efficient and effective method.

\section{THE METHOD OF RESEARCH}

\section{A. The model of Research}

The model of the research is descriptive research with quantitative approach by survey conducted on four sub-districts under Padangsidempuan for 2015.

\section{B. Location, the Scope, the Period of Research}

The research was conducted since June to December 2016 on Kota Padangsidempuan, located on Kecamatan(s) with PHBS moderately such as Kecamatan Padangsidempuan Batunadua, Padangsidempuan Hutaimbaru, Padangsidempuan Selatan, Padangsidempuan Utara [4]. This research was conducted for one year. The scope is with ten components of PHBS, have been observed on all homes and to field informant and to person in charge on Health promotion [4].

This study is qualitative and quantitative research. A quantitative research is an explanatory research, taken mainly to determine applicable point of cleanly and healthy living, still to analyze them to all locations, and provide the best health promotion management model, and study them with fishbone diagram. A qualitative research is by in-deeply interview over informant to know clearly and deeply about the implementation of health promotion program on Padangsidempuan.

\section{The Population and Sample of Research}

The population of research are those all families living on Kecamatan Padangsidempuan Batunadua with 4,816 houses, Padangsidempuan Hutaimbaru 3,733 Houses, Padangsidempuan Selatan is 14,8139 Houses, Padangsidempuan Utara 14,652 Houses, that total population are around 38,040 hosues [4].

In taking the sample was arranged bases the following formulation :

$$
\begin{aligned}
\mathrm{N} & =\mathrm{N} / 1+\mathrm{N}\left(\mathrm{d}^{2}\right) \\
& =99.7 \text { Respondents (rounded into 100, so }
\end{aligned}
$$

each Kecamatan 25).

\section{The Method of Collecting Data}

1) Primary Data

Primary data is data obtained from respondent directly. This data can be taken bu using questionnaire arranged in structure which all respondents are required to fill the answer in most reliable.

2) Secondary Data

Secondary data are taken from the source of profile for district Health Service, Puskesmas and sub-district administration having the data.

\section{E. The Method in Data Analysis}

In process all the data, in this study with SPSS program, either on editing, coding, scoring and tabulating. In analyzing the data, there used descriptive statistic (cross tab) test, and then display them in a frequency and percentage format. Further, the result shall be interpreted and analyzed to make own a health promotion management - PHBS model.

For variable of healthy and cleanly living, the data was collected by questionnaire, and then tabulate it and still classify them, later given score of answer according to the course of question such as to measure their knowledge rate (1) in correct answer with score 1, incorrect answer 0 , however to measure their attitude respond rate comprised very agree, agree, not agree and very no agree, the highest is with score 4, and the lowest is 1 , and to measure their action rate shall be given 2 for the best, for moderate is 1 , and noting is with 0 .

\section{THE RESULT OF RESEARCH}

\section{A. The Age and Tropical Diseases}

The age of respondents with tropical disease mostly in this research noted as adult newly adult noted 36 person and none of them as elder.

The mostly of respondent with tropical diseases in respiratory TB noted 61 people, on the last teenager aged noted 14 people, newly adult of 34 people, the last adult are 9 people, and newly elders are 4 people. The result indicated that tropical respiratory $T B$ disease on Padangsidempuan city mostly found on a productive aged group namely aged $14-50$ years old. In second rate with tropical disease noted with diarrhea around 29 people, on babies aged noted 17 people, kids noted 4 people, still newly teenagers and 
the last noted each 2 people. The research indicated its result that diarrhea found on Padangsidempuan community is mostly on kids [4].

\section{About the Gender and Tropical Disease}

It was found that mostly boys exposure to tropical disease some 55 people compared to girls noted 45 . Total patient with respiratory TB disease mostly are as male 49 people compared to women of 13 people. Patient with diarrhea disease found as male 16 people, and the women found 14 people. It has been found patient with dengue on women was 6 but man found 2 patients.

\section{Income Rate and Tropical Disease}

The average income of respondent mostly under Rp. 1,000,000 noted 59 homes. This result indicated that tropical disease is identical with poverty so those houses living under poverty line seemly be more exposed over tropical disease.

\section{Education Level and Tropical Disease}

The result indicated that the respondents' education level mostly in secondary level and above. The respiratory TB disease is mostly 38 to the family with secondary level education, with diarrhea noted 22, with dengue noted 2 people having secondary education. The respiratory TB disease also found on the families with higher education level of 15 people.

\section{Their Profession and Tropical Disease}

The kind of profession of those respondent with tropical disease on the city mostly noted as business-men 34 hoses due to this profession is more open exposure to environmental sanitary not clean. Having profession as Becak driver, informal business, not permanent business and as employee-private, mostly noted with respiratory TB 32 houses, as public employee noted 22 houses and farmer around 8 houses.

\section{Home Construction and Tropical Disease}

The home construction is so simply to this respondents either with ground base without any cement, home-wall noted in woody, roofing, poor ventilation cause clumsy air, having no any standard toilet, found alike simple noted 51 units, however existed patient with tropical disease as respiratory $\mathrm{TB}$ in 30 , diarrhea noted 15 patients and with dengue noted 6 patients.

\section{B. PHBS Rates and Tropical Disease on Padangsidempuan}

\section{Their Knowledge of PHBS and Tropical Disease}

Local people community with knowledge PHBS may influence their health rate in general, it means, the better their knowledge of PHBS shall influence their respond to prevent the disease away and then have a higher health status. On the Table 5.9 can be seen that mostly the respondents having a moderately knowledge about it noted 73 houses, but in poor knowledge noted 18 houses and with better knowledge noted 9 houses. As respiratory TB patients noted 62 people and $77.4 \%$ occurred to the respondents having moderate knowledge. Total patient with diarrhea noted 30 people, $63 \%$ to the respondents having a moderate knowledge. Total patient with dengue is 8 people, and $75 \%$ of them having a moderate knowledge.

\section{Attitude in PHBS and Tropical Disease on Location}

In the result of research mostly the respondent having a moderate attitude noted 90 people, in poor attitude noted 1 people, and valuable is noted 5 people by 100 in all. Still, having respiratory TB noted 62 people, and $95 \%$ of the respondent having a moderate attitude. Patient with diarrhea noted 30 people, and $80 \%$ is to the respondents having a moderate attitude.

\section{Having Action to PHBS and Tropical Disease}

One own action, is a natural realization having knowledge owned, in positive behave and supported to do. In this research noted 53\% of respondents having a poor to act, means one's knowledge and behave to do not or regret it mostly in the respondents.

\section{Monitoring in PHBS and Tropical Disease}

1) Field Survey over Water Sources in House In field survey, to their source of water the family take in having daily activities can be seen on Table 5.12. The result indicated that mostly respondents having their water noted such as noted $46 \%$ are from PDAM-local administration supplier 26\%, well $15 \%$, River $10 \%$, and rainy sources noted $3 \%$. 
2) Field Survey over Uses of soap

In field survey over the uses of soap they used in daily activities can be seen on Table 5.14. The result indicated that respondent usually use soap for bathing and shower mostly noted $80 \%$, use the soap for washing and laundry noted $80 \%$ and use soap to westafel noted $10 \%$.

3) The Result of Survey over the Latrine In field survey of PHBS over the latrine used for daily activities can be seen on Table 5.16. The result indicated that mostly respondents used type of goose-neck noted $43 \%$, latrine with hole-ground noted $38 \%$, closed-model $4 \%$ and poorly latrine throw-out to river directly noted $15 \%$.

4) Field Survey on Smoking Habits and Available ashtray

Field survey with PHBS over their habits of smoking and available any ashtray at home. The data can be seen on Table 5.18, noted that $89 \%$ respondents is smoking at home, and about $98 \%$ provide always ashtray for smoke.

5) Field Survey on Mosquito Larva

After having survey, known that around $28 \%$ of respondent in home found existed mosquito larva.

\section{The Uses of Method and Media Promotion of Health in PHBS}

In survey and research noted that the method ever the respondent found indicated by 100 respondents having ever method with open speech and discussion around $49 \%$, and the rest had no ever any more having any method in promotion to PHBS. This indicated that variously program of methods in promotion PHBS not fully realized to public on Padangsidempuan so the simulation to find the effective method is highly required.

\section{CONCLUSION AND SUGGESTIONS}

\section{A. Conclusion}

Based on the field research particularly on knowledge, attitudes and action as well as method, the media ever accepted by the respondent are as followings :

1. Respondent's knowledge with moderate category noted $73 \%$, poorly in $18 \%$, and in good noted $9 \%$. All patient with tropical disease (respiratory TB, Diarrhea, and Dengue), having a moderately knowledge.

2. The respondent's attitude on a moderate category is $90 \%$, poorly is $5 \%$, on good category is $5 \%$, this indicated that respondent with attitude to tropical disease is noted agree with it.

3. The respondent's action on the tropical disease with poor category is noted $53 \%$, moderate $22 \%$, and good $25 \%$, means for action category is not conformed to their knowledge category and attitudes as respondent.

4. The field survey indicated that those respondent have their drinking water highly clean is water there using re-fill gallon noted $46 \%$, PDAM $26 \%$, well digging $15 \%$, by river $10 \%$, and rainy water noted $3 \%$. In the result, the factor of cause a tropical disease particularly diarrhea the source of water is digwater $12 \%$, while in source water with re-fill noted $8 \%$.

5. Washing-hand use-soap, based on field survey indicated that $80 \%$ object of soap found in bath-room, soap in waste-fall, as well for handwashing only $10 \%$. This may cause diarrhea due to the soap found on bathroom, for a flowing water it is not used anymore.

6. Type of latrine as found in field, indicated $53 \%$ of respondent having no any health latrine noted such as base-ground and river, this kind surely may cause and influence diarrhea disease.

7. On smoking, in generally $98 \%$ of respondent got smoke at home, and $98 \%$ provided ashtray at home, this closed relation with cause tropical disease mainly on respiratory TB.

8. On mosquito larvae in surrounding indicated $28 \%$ found the larvae around home, this is highly risk to cause dengue (DBD), in actually $8 \%$ of patient with dengue.

9. The method ever applicable is with speech noted $32 \%$, discussion $7 \%$, and the highest rate ever having any method about the topic PHBS, this indicated highly risks to tropical disease, proved highly occurrence respiratory $\mathrm{TB}$, they have no information how to prevent the respiratory $\mathrm{TB}$.

10. The media ever used highest noted media TV in $33 \%$, however just about smoke, by leaflet in $27 \%$ by medical personnel and students, still $6 \%$ by religious leader. This means that in method there is $40 \%$ having no information 
from any media, they have no any information about PHBS.

\section{A. Suggestions}

1. Based on the above conclusion is suggested highly provide special model perhaps in order improve knowledge, attitude and action by local community of Padangsidempuan by media not-watching only but in motion through video and film about PHBS, method of FGD as well as open discussion also with any games, in addition necessary done deeper the theory of PHBS.

2. It is necessary provided a policy in advocate for handling the problem PHBS, particularly on infrastructures and superstructures how to deal with it.

3. It is urged to have another advanced research about public figures' attitudes.

4. For the advocates, public health service, people figures should cooperate hand in hand to deal with PHBS and to be more care how to prevent tropical disease.

5. It is necessary to conduct any games annually to encourage those public participation on PHBS appropriate in field, provide there existed attractive prizes and be valuable to those people.

\section{Reference}

[1] Ambarwati, et al., 2014. MediaLeaflets, Video and Knowledge Elementary Students Dangers of Smoking (Study on Student SDN 78 Sabrang Lor Mojosongo Surakarta). Journal Pack. 10 (1): 7-13.

[2] Cheppy Riyana. 2007. Guidelines for Development of Media Video. Jakarta: P3AI UPI.

[3] MOH 2009.Rumah Appliances Behaving Clean And Sehat.Jakarta: MOH.North Sumatra Provincial Health Office. 2012. Health Profile 2012. Medan North Sumatra: Dinkes Provinsi Sumutera Utara.

[4] Padang sidimpuan City Health Department. 2015. Final Report Survey Behavior Clean and Healthy Lifestyle (PHBs) Padang sidimpuan City Year 2015 Padang sidimpuan City: Mulberry City Health Office.

[5] Kapti, R., E., 2010, The Effectiveness of Health Education Audiovisual Media As to Increase Knowledge and Attitude Women in Management of Two Toddlers with Diarrhea in Malang.Tesis City Hospital. Faculty of Nursing Master Program in Nursing at the University of Indonesia, Depok

[6] Ministry of Education and Culture. 2013 Modules PHBs (Behavior Clean and Healthy). Surakarta: Univeristy of March.

[7] Machfoedz, Ircham and Eko Suryani. 2008. Health Education Section of Health Promotion. Yogyakarta: Fitramaya.

[8] Notoatmodjo Soekidjo 2013, Health Promotion and Science behavior.Jakarta: Rineka Reserved.

[9] Proverawati, Atikah and Eni Rahmawati.2012. PHBs behavior Clean \& Healthy Living. Jakarta: Nuha Medika.

[10] Sugiyono. 2010. Qualitative and Quantitative Research Methods $R$ \& D. Bandung: Alfabeta
[11] WHO., 2010. The World Health Report 2010. http://www.who.int./whr/2010/en/index.html Akses 18 Desember 2015 